\title{
Lymphocyte response to hepatitis B surface antigen
}

\section{Findings in hepatitis and Indian childhood cirrhosis}

\author{
R. K. CHANDRA \\ From the Department of Paediatrics, All India Institute of Medical Sciences, New Delhi, India
}

\begin{abstract}
Chandra, R. K. (1975). Archives of Disease in Childhood, 50, 559. Lymphocyte response to hepatitis $B$ surface antigen: findings in hepatitis and Indian childhood cirrhosis. The lymphocyte delayed hypersensitivity response to phytohaemagglutinin (PHA) and hepatitis B antigen (HBsAg) was evaluated by two in vitro tests-leucocyte migration inhibition and DNA synthesis. Patients convalescing from $\mathrm{HBsAg}$-positive hepatitis showed the presence of a state of cell-mediated immune responsiveness to the antigen. In Indian childhood cirrhosis, there was a failure of response to HBsAg and a slight but significant depression of reaction to PHA. It is suggested that the lack of immune reactivity to $\mathrm{HBsAg}$, perhaps determined genetically, may be a significant factor in the evolution of cirrhosis in Indian children.
\end{abstract}

Cirrhosis of the liver is a major killer of young children in India. It has a characteristic clinical (Achar, Raju, and Sriramachari, 1960) and histopathological (Liver Disease Subcommittee, 1955) picture. Epidemiological data (Achar et al., 1960; Chawla et al., 1973) and evolution of histomorphological changes (Aikat and Srivastava, 1956) suggest an important pathogenetic role of hepatitislike illness. Hepatitis B surface antigen (HBsAg, Australia antigen, hepatitis-associated antigen) is detected in a significant proportion of affected children (Chandra, 1970) and may persist in the serum, other body fluids, and excretions for weeks and months, suggesting a failure of lymphocytemediated immunity to eliminate the virus. There is mild to moderate impairment of cellular immunity, as judged by cutaneous delayed hypersensitivity to common antigens and lymphocyte transformation response to phytohaemagglutinin (PHA) (Chandra, et al., 1972) but this may well be a consequence of inanition brought about by a serious illness. Since these patients tolerate other infections reasonably well, it was considered desirable to look at the specific reactivity of lymphocytes to HBsAg.

\section{Materials and methods}

Subjects. Four groups of children were studied. 10 were patients with the diagnosis of Indian childhood cirrhosis based on clinical features and histological ex-

Received 6 December 1974. amination of percutaneous and needle biopsy of the liver. Their ages were from 11 to 36 months. All were boys and had shown HBsAg in the serum at some stage of their illness. 10 male patients with $\mathrm{HBsAg}$ positive hepatitis were studied $\mathbf{2}-24$ weeks after clinical recovery. By the time of the study, all had become negative for HBsAg. Their ages ranged from 15 to 36 months.

Four children with postnecrotic cirrhosis negative for $\mathrm{HBsAg}$ and antiHBs were also investigated. 10 healthy children with no history of jaundice or blood transfusion, matched for age and sex, served as controls. Their sera were negative for $\mathrm{HBsAg}$ and anti-HBs.

Hepatitis antigen and antibody. HBsAg and anti-HBs were detected initially by counterimmunoelectrophoresis and confirmed later by radioimmunoassay.

Lymphocyte stimulation response. Cell separation was achieved by Ficoll-Hypaque gradient centrifugation. Cells were washed twice and cultures established containing $2 \times 10^{6}$ lymphocytes/ml in medium $199+$ $15 \%$ pooled AB serum. Lymphocyte cultures were set up in triplicate. To one set of cultures, PHA was added in doses of 3,30 , and $300 \mu \mathrm{g} / \mathrm{ml}$ and the cells harvested at 96 and 120 hours. For analysis of results, values of cultures stimulated with $30 \mu \mathrm{g} / \mathrm{ml}$ PHA and examined at 96 hours were used, since these culture conditions yielded maximum counts. To the second set of cultures, HBsAg purified by isopyknic fractionation and zonal centrifugation was added in a concentration of $200 \mu \mathrm{g} / \mathrm{ml}$ and the cells examined at 120 hours, since these dose-time variables achieved maximum 
stimulation. The third set was kept as unstimulated control. DNA synthesis was measured by ${ }^{3} \mathrm{H}$-thymidine incorporation using a scintillation counter. The morphology of 200 cells was studied for blast transformation.

Leucocyte migration inhibition. The method of Bendixen and Soborg (1969) was followed. Heparinized venous blood was allowed to sediment at $37^{\circ} \mathrm{C}$, the leucocyte rich plasma was removed and centrifuged at $120 \mathrm{~g}$ for 20 minutes at $15^{\circ} \mathrm{C}$. The cell pellet was resuspended in medium 199 containing $20 \%$ fetal calf serum and penicillin-streptomycin, and made up to a concentration of $10^{7}$ mononuclear cells $/ \mathrm{ml}$. The cells were packed into a capillary tube, centrifuged, and the glass tube cut at the cell-liquid interface. The capillaries were laid in specially contrived chambers containing culture medium with or without HBsAgcontaining serum and incubated at $37^{\circ} \mathrm{C}$ for 24 hours. Migration of cells into the medium was measured by planimetry and calculated by the formula $\mathrm{Aa} / \mathrm{Ao} \times 100$, where $\mathrm{Aa}$ is the area of migration in the presence of $\mathrm{HBsAg}$ and Ao the area of migration in the absence of HBsAg.

\section{Results}

Lymphocytes of children convalescing from HBsAg-positive hepatitis showed a significant (P $<0.01$ ) increase in DNA synthesis when cultured in the presence of HBsAg (Table). This was corroborated by examination of cell morphology to detect lymphoblasts. Cells of healthy controls negative for $\mathrm{HBsAg}$ and anti-HBs, and cells of $\mathrm{HBsAg}$-positive cirrhotic patients did not have increased ${ }^{3} \mathrm{H}$-thymidine incorporation on stimulation with the antigen. With PHA, the lymphocyte transformation response was comparable in control and hepatitis groups, and slightly but significantly reduced $(P<0.05)$ in cirrhosis.

Leucocytes of convalescent patients with hepatitis had significant $(P<0.01)$ inhibition of migra- tion in the presence of HBsAg (Table). The migration of cells obtained from cirrhotics was comparable to that of controls, confirming the lack of a state of hypersensitivity to $\mathrm{HBsAg}$ in each of the groups.

\section{Discussion}

The consequences of contact with material containing HBsAg are variable, from the asymptomatic to the fulminant (Dudley, Fox and Sherlock, 1971; Chandra, 1974a), and such contact may also lead to a chronic carrier state, cirrhosis, or hepatoma. It is likely that host factors, especially the immune response, are significant in determining the outcome. Besides nonspecific factors, antibodies and lymphocyte-mediated specific reactivity help in the elimination of pathogens. For viruses, cellular immunity seems more important.

We have employed two in vitro tests to evaluate the presence of a specific immune state of delayed hypersensitivity to $\mathrm{HBsAg}$. The unequivocal inhibition of leucocyte migration and stimulation of lymphocyte DNA synthesis in patients with hepatitis indicated the existence of such a state. This was not observed in healthy controls who had no evidence of infection with $\mathrm{HBsAg}$ in the past. Using serum rich in $\mathrm{HBsAg}$, Yeung Laiwah (1971) and his colleagues (Yeung Laiwah, Chaudhuri, and Anderson, 1973) found that blast transformation of lymphocytes occurred in patients with serum hepatitis. Recently in vivo and in vitro delayed hypersensitivity to purified $\mathrm{HBsAg}$ has been shown in chimpanzees (Ibrahim, Vyas, and Prince, 1974) and in man (Ibrahim, Vyas, and Perkins, 1975).

Failure to show a specific immune reactivity to HBsAg in Indian childhood cirrhosis is intriguing, since HBsAg had been shown in the serum of these

TABLE

Hepatitis $B$ surface antigen (HBs $A g$ ) and antibody (anti-HBs), lymphocyte stimulation, and leucocyte migration. (Mean and range of values are given)

\begin{tabular}{|c|c|c|c|c|c|c|c|c|}
\hline \multirow{2}{*}{$\begin{array}{l}\text { Group } \\
\text { (and no.) }\end{array}$} & \multicolumn{2}{|c|}{ No. positive } & \multicolumn{3}{|c|}{$\begin{array}{l}\text { Lymphocyte DNA } \\
\text { synthesis (cpm) }\end{array}$} & \multicolumn{2}{|c|}{$\begin{array}{c}\text { Blast } \\
\text { transformation (\%) }\end{array}$} & \multirow{2}{*}{$\begin{array}{c}\text { Leucocyte } \\
\text { migration } \\
\text { in } \\
\text { presence of } \\
\text { HBsAg }(\%)\end{array}$} \\
\hline & HBsAg & anti-HBs & $\begin{array}{l}\text { Saline } \\
\text { control }\end{array}$ & PHA & HBsAg & PHA & HBsAg & \\
\hline Healthy (10) & 0 & 0 & 236 & $\begin{array}{c}14132 \\
(0871-23681\end{array}$ & 102 & 82 & ${ }^{7}$ & 121 \\
\hline Hepatitis (10) & 10 & 3 & $\begin{array}{c}121 \\
(107-159)\end{array}$ & $\begin{array}{c}10361 \\
(7671-17639)\end{array}$ & $\begin{array}{c}1137 \\
(857-1813)\end{array}$ & $\begin{array}{c}80 \\
(65-91)\end{array}$ & $\begin{array}{c}58 \\
(42-82)\end{array}$ & $\begin{array}{c}58 \\
(20-85)\end{array}$ \\
\hline $\begin{array}{l}\text { Indian childhood } \\
\text { cirrhosis }(10)\end{array}$ & 10 & 1 & $\begin{array}{c}258 \\
(112-337)\end{array}$ & $\begin{array}{c}5297 \\
(4176-7103)\end{array}$ & $\begin{array}{c}108 \\
(80-136)\end{array}$ & $\begin{array}{c}55 \\
(43-73)\end{array}$ & $\begin{array}{c}14 \\
(3-42)\end{array}$ & $\begin{array}{c}103 \\
(75-130)\end{array}$ \\
\hline $\begin{array}{l}\text { Postnecrotic } \\
\text { cirrhosis (4) }\end{array}$ & 0 & 0 & $\begin{array}{c}196 \\
(139-251)\end{array}$ & $\begin{array}{c}7368 \\
(5913-14032)\end{array}$ & $\begin{array}{c}143 \\
(96-210)\end{array}$ & $\begin{array}{c}71 \\
(53-86)\end{array}$ & $\begin{array}{c}11 \\
(5-23)\end{array}$ & $\begin{array}{c}87 \\
(79-96)\end{array}$ \\
\hline
\end{tabular}


patients at some stage of their illness. There was no significant increase in spontaneous release of migration inhibition factor (MIF) from lymphocytes of patients, so the lack of augmentation of the response with HBsAg is not a likely result of lymphocyte stimulation in vivo. The absence of increased DNA synthesis in unstimulated cultures lends support to this explanation.

The lymphocyte DNA synthesis in response to PHA was only mildly impaired in Indian childhood cirrhosis, which may be the result of changes in the metabolic milieu and inanition associated with a serious illness, and excludes a marked general depression of cellular immunity. It is likely that the lack of lymphocyte immune response to $\mathrm{HBsAg}$ in such patients permits persistence of antigenaemia and continued progressive liver cell damage. An analogous situation is seen in patients with generalized necrotic vaccinia after smallpox immunization, in whom there may be a failure to develop delayed hypersensitivity to the virus, dissociated from antibody synthesizing capacity and cellular response to other agents (Fulginiti, et al., 1966).

Three patients, who were sibs of previously confirmed cases of Indian childhood cirrhosis, had been tested and found to be negative for HBsAg and anti-HBs before the onset of symptoms. This would make it unlikely that the lack of immune response was due to the phenomenon of tolerance seen in asymptomatic HBsAg carriers (Yeung Laiwah et al., 1973), especially in those who acquire the infection early in postnatal life (R. K. Chandra, unpublished data).

The immunological abnormality in Indian childhood cirrhosis may well be determined genetically since the disease has a peculiar geographical distribution. There is a familial aggregation of cases (Achar et al., 1960), abnormal dermatoglyphs (Chandra, 1969) and the segregation ratio on genealogical analysis suggests inheritance on an autosomal recessive basis (Chandra, 1974b). The concept of a particular genetic soil predisposing to persistent virus infection is new but logical. The capacity to mount a $T$ (thymus-dependent) cell response to certain defined antigens is controlled genetically in some animals, the ability to respond being transmitted as a single mendelian autosomal characteristic. These genes have been named the Ir (immune response) genes, and are linked to the loci bearing the principal transplantation antigens or those governing reactivity in the mixed lymphocyte reaction.

It is suggested that Indian childhood cirrhosis may develop from infection with hepatitis $B$ virus in a genetically predisposed infant, and that failure to mount an adequate immune response results in persistent antigenaemia, progressive liver cell necrosis, and death. Most of the biochemical and immunological abnormalities described in the syndrome (Chandra 1968, 1970, 1974b; Chandra et al., 1972) are epiphenomena or the consequence of liver injury rather than the cause of it.

I am grateful to Professor O. P. Ghai for encouragement and permission to publish; to Professor G. P. Talwar and Dr. K. Balakrishnan for the use of laboratory facilities; and to several physicians who have allowed access to patients and provided valuable reagents.

\section{REFERENCES}

Achar, S. T., Raju, V. B., and Sriramachari, S. (1960). Indian childhood cirrhosis. Fournal of Pediatrics, 57, 744.

Aikat, B. K., and Srivastava, J. R. (1956). The probable mode of evolution of infantile cirrhosis. Indian Fournal of Medical Sciences, 10, 186.

Bendixen, G., and Soborg, M. (1969). A leucocyte migration technique for in vitro detection of cellular (delayed type) hypersensitivity in man. Danish Medical Bulletin. 16, 1.

Chandra, R. K. (1968). Gastric acid secretion with maximal augmented histamine stimulation in Indian childhood cirrhosis. fournal of Tropical Medicine and Hygiene, 71, 150.

Chandra, R. K. (1969). Dermatoglyphics in Indian childhood cirrhosis. Human Heredity, 19, 540.

Chandra, R. K. (1970). Immunological picture in Indian childhood cirrhosis. Lancet, 1, 537.

Chandra, R. K. (1974a). The liver and biliary system. Paediatric Gastroenterology. Ed. by C. M. Anderson and V. Burke. Blackwell, Oxford.

Chandra, R. K. (1974b). Indian childhood cirrhosis. Clinical, biochemical, genealogical, histomorphological and immunological observations. Médecine et Chirurgie Digestives, 3, 63.

Chandra, R. K., Chawla, V., Verma, I. C., Ghai, O. P., and Malik, G. R. (1972). Hepatitis-associated antigen and depressed cellular immunity in Indian childhood cirrhosis. American fournal of Diseases of Children, 123, 408.

Chawla, V., Chandra, R. K., Verma, I. C., and Ghai, O. P. (1973). Epidemiologic approach to Indian childhood cirrhosis. Indian Pediatrics, 10, 73.

Dudley, F. J., Fox, R. A., and Sherlock, S. (1971). Relationship of hepatitis-associated antigen (HAA) to acute and chronic liver injury. Lancet, $2,1$.

Fulginiti, V. A., Hathaway, W. E., Pearlman, D. S., Blackburn, W. R., Reiquam, C. W., Githens, J. H., Claman, H. N., and Kempe, C. H. (1966). Dissociation of delayed-hypersensitivity and antibody-synthesising capacities in man. Lancet, 2, 5.

Ibrahim, A. B., Vyas, G. N., and Perkins, H. A. (1975). Immune response to hepatitis $\mathrm{B}$ surface antigen. Infection and Immunity. (In press.)

Ibrahim, A. B., Vyas, G. N., and Prince, A. M. (1974). Studies on delayed hypersensitivity to hepatitis $B$ antigen in chimpanzees. Clinical and Experimental Immunology, 17, 311.

Liver Disease Subcommittee (1955). Infantile cirrhosis of the liver in India. Indian fournal of Medical Research, 43, 369.

Yeung Laiwah, A. A. C. (1971). Lymphocyte transformation by Australia antigen. L.ancet, 2, 470.

Yeung Laiwah, A. A. C., Chaudhuri, A. K. R., and Anderson, J. R. (1973). Lymphocyte transformation and leucocyte migrationinhibition by Australia antigen. Clinical and Experimental Immunology, 15, 27.

Correspondence to Professor R. K. Chandra, Memorial University, St. John's, Newfoundland, Canada A1C 5 S7. 